\title{
Altered Testicular Morphology and Oxidative Stress Induced by Cadmium in Experimental Rats and Protective Effect of Simultaneous Green Tea Extract
}

\author{
Morfología Testicular Alterada y Stress Oxidativo Inducido por Cadmio en Ratas \\ de Experimentación y el Efecto Protector del Extracto Simultáneo del Té Verde
}

*Abd El-Rahman El-Shahat; ${ }^{* *}$ Attia Gabr; ${ }^{* * *}$ Abdel-Raheim Meki \& ${ }^{* * * * *}$ El-Saed Mehana

EL-SHAHAT, A. E.; GABR, A.; MEKI, A. R. \& MEHANA, E. S. Altered testicular morphology and oxidative stress induced by cadmium in experimental rats and protective effect of simultaneous green tea extract. Int. J. Morphol., 27(3):757-764, 2009.

SUMMARY: Cadmium (Cd), is an environmental and industrial pollutant that affects the male reproductive system. Cd induces its effect by affecting tissue antioxidant enzyme systems. Green tea extract (GTE) is an antioxidant and free radicals scavenger and has a chelating property. The purpose of this study was to investigate the protective effect of GTE against testes damage induced by Cd. Four groups of male rats, were utilized as following: Controls, GTE treated, Cd treated and Cd + GTE, treated rats at the same doses. The rats received GTE and or Cd orally in drinking water. After 5 weeks, the animals were sacrificed and testes were removed for microscopic and Biochemical evaluation. The levels of lipid peroxides (LPO) and glutathione (GSH) were detected in the tissue homogenates of rat testes. The current study showed marked morphological changes in the form of swelling, congestion, hemorrhage and necrosis in testes of rats treated with $\mathrm{Cd}$ alone. However, the rats treated with $\mathrm{Cd}+\mathrm{GTE}$ showed milder edema, congestion and minute foci of necrosis in the testes. The LPO levels were significantly higher as compared to control and of GSH were significantly lower in Cd-treated rats but when GTE was co-administrated with $\mathrm{Cd}$, there was an effective reduction in oxidative stress as shown by a significant rise of GSH level. In conclusion, the rats received GTE + Cd could enhance antioxidant/ detoxification system which consequently reduced the oxidative stress in rat testes. The beneficial effect of GTE is thus potentially reducing Cd toxicity and tissue damage.

KEY WORDS: Rat Testes; Cadmium toxicity; Green tea extract; Lipid peroxides; Glutathione.

\section{INTRODUCTION}

The humans are exposed to various types of environmental contaminants at different stages of their life span; the majority of these are harmful. Cadmium $(\mathrm{Cd})$ is considered to be one of the most toxic heavy metals. Exposure to $\mathrm{Cd}$ as a result of industrial and environmental pollution leads to dangerous health hazards. Cd has been found to produce wide range of biochemical and physiological dysfunctions in humans and laboratory animals (Santos et al., 2004). Cd is a by-product of the mining and smelting of lead and zinc. It is used in nickel-cadmium batteries, dyes, plastics, electrochemistry and paint pigments. It can be found in soils because insecticides, fungicides, sludge and commercial fertilizers containing $\mathrm{Cd}$ that are used in agriculture (Robards \& Worsfold, 1991). In addition, Cd is carcinogenic metal to which humans are exposed through contaminated foods, water or air. Chronic Cd poisoning can result in nephrotoxicity, osteoporosis, cardiovascular diseases, testicular necrosis, prostatic and testicular cancers, renal failure and neurodegenerative conditions ( $\mathrm{Yu}$ et al., 2007; Diana, 2008).

In Cd -exposed mammals, many target organs are affected including the testes, brain, liver and kidneys (Liu $e t$ al., 1996; Oteiza et al., 1999; Shaikh \& Tang, 1999). Santos reported that the most marked effect in rats given a single parentral dose of $\mathrm{Cd}$ was testicular necrosis. Moreover, it

* Lecturer, Department of Anatomy, Faculty of Medicine, Cairo University, Egypt.

** Lecturer, Department Pharmacology, Faculty of Medicine, Suez Canal University, Egypt.

*** Professor, Department of Biochemistry, Faculty of medicine, Assuit University, Egypt.

${ }^{* * * * *}$ Lecturer, Department of Pathology, Faculty of Veterinary Medicine, Alexandria University, Egypt. 
was reported that spermatogenesis is disturbed by free radical toxicity. Thus, the study of oxidative stress is a determinant in exploring some aspects affecting fertility (Aruldhas et al., 205). Cd depletes many essential metal antioxidants including selenium in the body (Sato \& Takizawa, 1982). Oxidative stress occurs as a result of an increase in $\mathrm{Cd}$-induced peroxidation of membrane lipids in the organs when it accumulates (Anderson \& Anderson, 1988; Liu et al.).

Cd exposure results in decreases in glutathione (GSH) levels which causes an increase in reactive oxygen species like hydrogen peroxide, hydroxyl radicals and superoxide radical ions, leading to increase lipid peroxidation, change intercellular stability, damage deoxyribonucleic acid (DNA), membranes and consequently inducing cell death (Stohls et al., 2001). Moreover, Gupta et al. (2004) reported that Cd possesses a strong affinity to thiol groups of amino acids, especially cystein. It has been revealed that $\mathrm{Cd}$ may affect the antioxidant barrier via inhibiting the functional thiol groups of antioxidant enzymes.

GSH is not only reacts with free radicals, but also can form conjugates with heavy metals leading to their detoxification. It binds with heavy metals and the resulting water soluble metal is more easily filtered out of the body (Kara et al., 2005). Moreover, GSH via direct reaction with free radicals and involvement, as substrate or cofactor, in enzymatic antioxidant reactions, also protects cells against oxidative stress (García-Fernández et al., 2002).

Many investigators proposed that one possible mechanism of $\mathrm{Cd}$ toxicity is the disturbance of prooxidant and antioxidant balance by generation of reactive oxygen species (ROS) (Kara et al.). Tissue levels of lipid peroxide is proven an indicator of oxidative stress (Tandon et al., 2003; Alvarez et al., 2004). Furthermore, many investigators recoded that acute, as well as chronic $\mathrm{Cd}$ exposure is associated with elevated lipid peroxidation (LPO) in many organs including male sex organs (Gupta et al.; Kara et al.).

The use of herbal medicine increases every day and still finds a wide use worldwide. Traditional herbs have more acceptance than prescription drugs in many cultures. This was mostly attributed to being safer than drugs, from the point of view of patient. Also patients believe that by using this type of medication, there is no need for physician and it may be a relevant attempt to compensate for drug failure. Some of these alternatives were green tea (Camellia sinensis). Different studies showed that both green and black tea contain flavenoids such as quercetin, kaempferol and myricetin, which are potent antitoxic and anti-carcinogenic effects (Hertog et al., 1993; Challa et al., 1997). Much more research studies were done on green tea as antioxidants as it removes free radicals in human body, reducing the risk of heart disease, the stroke, thrombosis of the blood vessels and blood sugar levels.

Green tea has been found to aid in heavy metal detoxification by inhibiting its absorption and promoting excretion. Another potential effect due to the antioxidant activities of green tea polyphenols such as catechin, which binds with $\mathrm{Cd}$ ions to form an insoluble complex -ionic salt that was used to remove $\mathrm{Cd}$. Catechin normalizes testes metabolic disorders in $\mathrm{Cd}$ - poisoned rats (Paul, 2008).

The aim of the present study was to throw a light on cytoprotective effects of green tea extract as a model of powerful antioxidant against the toxic effects of cadmium chloride on the testes of male albino rats.

\section{MATERIAL AND METHOD}

Chemicals. The cadmium chloride, thiobarbituric acid, butylated hydroxytoluene, reduced glutathione, 5',5'dithiobis-2-nitro-benzoic acid were from Sigma (USA). All other chemicals used were of analytical grade.

Animal treatment. Sixty healthy male Sprague-Dawley rats (age: 14-16 weeks and about 170-200g body weight) were purchased from Animal House, college of pharmacy, King Saud University. All animals were conditioned at room temperature $\left(22-25^{\circ} \mathrm{C}\right)$ at a natural photoperiod for one week before experiment execution. A commercial balanced diet and tap water ad libitum were provided. The duration of experiment was 5 weeks.

They were randomly divided into 4 groups (15 rats each) as the following: Group I (Control group) receives distilled water as sole drinking source. Group II (GTE group) received green tea extract $(1.5 \% \mathrm{w} / \mathrm{v})$ of beginning of experiment. Group III (Cd group) received cadmium chloride at dose of $0.4 \%$ w/v in distilled water. Group IV (Cd + GTE group) received mixture of cadmium chloride and GTE as sole drinking source. The GTE was made according to Maity et al. (1998) by soaking $15 \mathrm{~g}$ of instant green tea powder in $1 \mathrm{~L}$ of boiling distilled water for 5 minutes. The solution was filtered to make $1.5 \%$ GTE. This solution was provided to rats as their sole source of drinking water. After 5 weeks, the animals of different groups were sacrificed under light anesthesia 1 day after the end of the treatment. The testes were excised immediately and divided into two parts, one for biochemical investigation and the other for histological examination. 
Biochemical analysis. The tissues of testes of different groups were homogenized in ice-cold $100 \mathrm{mM}$ phosphate buffer (pH7.4), using a Potter-Elvehjem homogenizer fitted with a taflon Plunger. Homogenates were centrifuged at $11,000 \mathrm{~g}$ for $20 \mathrm{~min}$ and the resulting supernatants were divided into aliquots and stored at $-80^{\circ} \mathrm{C}$. The levels of lipid peroxides (LPO) were measured in tissue homogenates as thiobarbituric acid reactivity (TBARS). The product of the reaction between malondialdehyde and thiobarbituric acid was measured as described by Thayer (1984). GSH levels in tissue homogenates were measured employing $0.04 \%-5,5 \%$ dithiobes-(2-nitrobenzoic acid) in $10 \%$ sodium citrate and recording at $410 \mathrm{~nm}$ as described by Dutta et al. (1995).

Histological slides preparation. Specimens from testicular tissues were fixed in $10 \%$ neutral buffer formalin, dehydrated in ascending grades of ethanol alcohols, cleared in xylol, casted, blocked, cut at 2-5 $\mu \mathrm{m}$ thickness and stained with hematoxylin-eosin for microscopic examination (Bancroft, 1975).
Statistical analysis. The results are expressed as mean \pm standard error (SE). Differences between groups were assessed by one-way analysis of variance (Bonferroni test) using the Prism version 5 software package for Windows. The level of significance was accepted with $\mathrm{P}>0.05$.

\section{RESULTS}

Biochemical results. The levels of LPO in the tissues homogenates of testes were significantly higher in Cd-group than control group. In the GTE+Cd group, the levels of LPO in the studied tissues were significantly reduced comparing to Cd-group (Table I and Fig. 1).

The levels of GSH in the tissues homogenates of testes were significantly declined in Cd-group comparing with controls. In the GTE+Cd group, the levels of GSH were significantly elevated in comparison with Cd-treated group (Table I).

Table I. Levels of lipid peroxides and glutathione in tissue homogenates of rat testes of different treated groups.

\begin{tabular}{ccccc}
\hline Variables & Controls & GTE-treated group & Cd-treated group & Cd + GTE-treated group \\
\hline $\mathbf{n m o l} / \mathbf{m g}$ protein) & $0.5987 \pm 0.0298$ & $0.5666 \pm 0.0262$ & $2.323 \pm 0.1822 * * *$ & $1.320 \pm 0.06758 \$ \$ \$$ \\
$\mathbf{n m o l} / \mathbf{m g}$ protein) & $16.86 \pm 0.6058$ & $15.04 \pm 0.6681$ & $6.590 \pm 0.6955 * * *$ & $12.46 \pm 0.7890 \$ \$ \$$ \\
\hline
\end{tabular}

Values are means $\pm \mathrm{SE}$ for 15 rats. $\mathrm{P}$ values are shown as ***,P<0.001 for comparison Cd-treated group and GTE-treated group versus controls. $\$ \$ \$, P<0.001$ for comparison $\mathrm{Cd}+\mathrm{GTE}$ group versus $\mathrm{Cd}$-treated group. Other details are given in materials and methods.

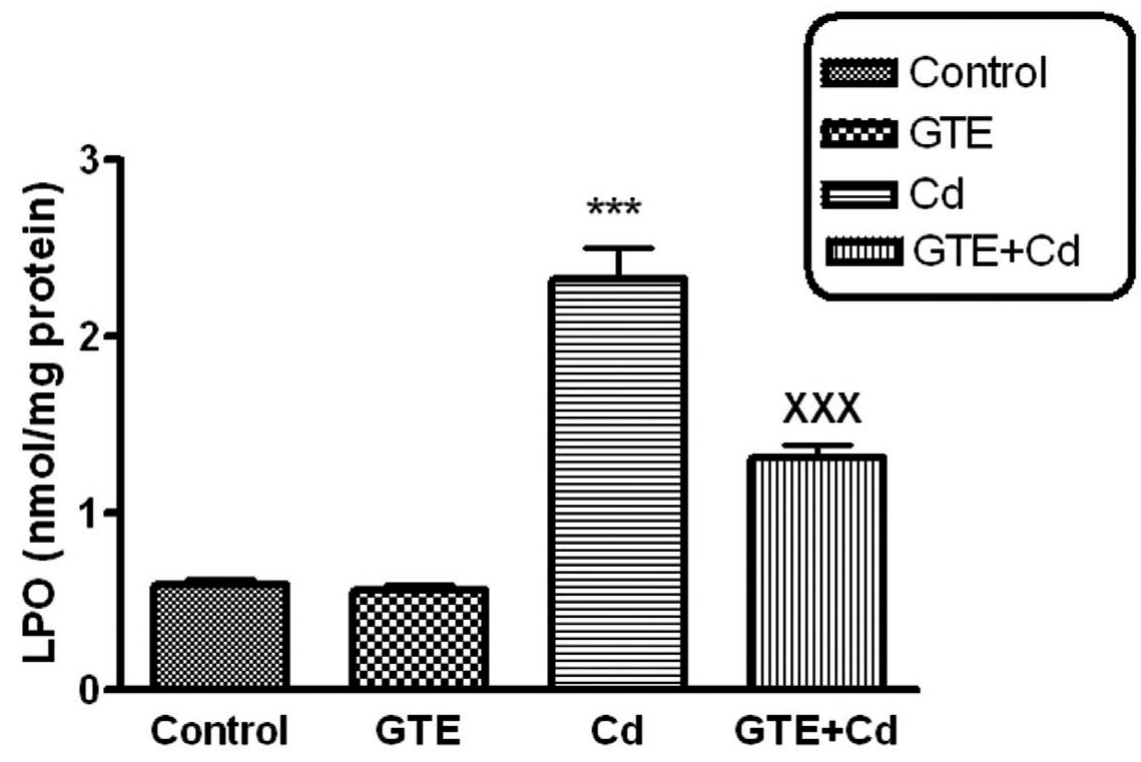

Fig. 1. Lipid peroxide (LPO) levels in tissues of testes of different treated groups. Data are mean \pm SEM. $* * * \mathrm{P}<0.001$ for $\mathrm{Cd}$ vs controls; $\mathrm{xxxP}<0.001$ for $\mathrm{GTE}+\mathrm{Cd}$ vs $\mathrm{Cd}$ 


\section{Histopathological results.}

Macroscopic changes. The testes of male albino rats intoxicated with $\mathrm{Cd}$ chloride alone showed edematous swelling, congestion, hemorrhage and focal to multifocal white, pale depressed areas of ischemic necrotic patches. The testes of rats, treated with Cd+ GTE showed mid degenerative changes, mild edema and congestion. The testes of normal control rats as well as GTE -treated rats showed the normal architecture of the testes.

Microscopic changes. The normal architecture of testicular seminiferous tubules and interstitial spaces were shown in the control rats (Fig. 3). In 7 rats out of 15 , the testes of rats, intoxicated with Cd chloride alone showed an extensive widening of the interstitial spaces, necrosis, congestion and

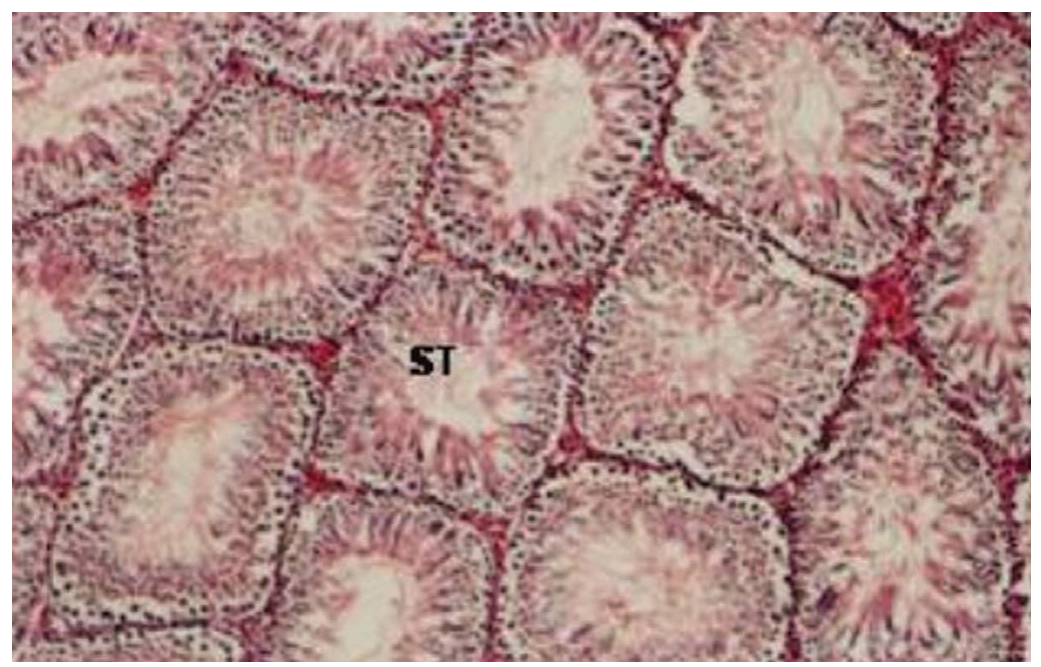

Fig. 3. Testes of male albino rats showing normal " control " structure of seminiferous tubules "ST" (H\&E .X 200).

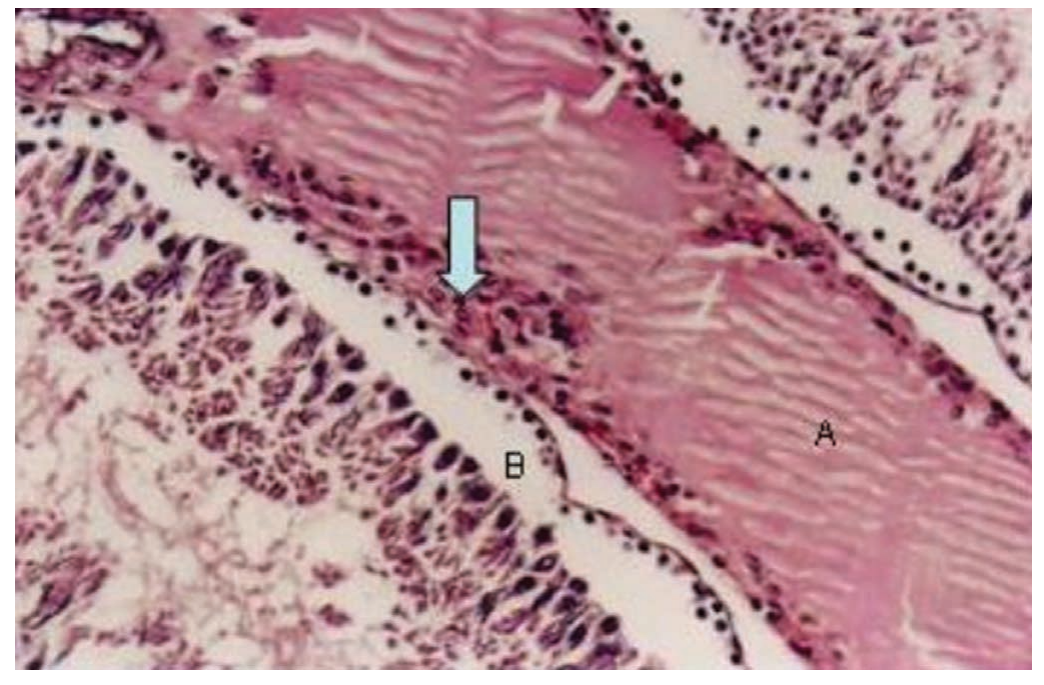

Fig. 4. Testes of male albino rats intoxicated with cadmium chloride alone showing widening interstitial space and diffuse edematous changes (A) with mononuclear cells infiltrations (Hollow arrow) besides basement membranes separating from the underlying layers(B) (H\&E. X .200). hemorrhage as well as mononuclear leukocytic cells infiltration besides basement membrane separating it from the underlying layers (Fig. 4-6). Moreover, in 5 out of 15 rats which were intoxicated with $\mathrm{Cd}$ chloride showed complete necrosis and sloughing of all layers of seminiferous tubules (Fig. 7). Moreover, in advanced cases ( 3 out of 15 cases), there were cystic dilatation of some seminiferous tubules however, others were atrophied with interstitial fibrosis and mononuclear inflammatory cells infiltrations (Fig. 8).

The testes of rats, treated with Cd+GTE showed mild to moderate edema, congestion with minute foci of necrosis and hemorrhage (Fig. 9-10). No detectable histological alterations showed in the testes of rats treated with GTE alone.

\section{DISCUSSION}

$\mathrm{Cd}$ is widely distributed in the environment because of its many industrial applications. The health risk to humans from acute and chronic $\mathrm{Cd}$ exposure has been well documented. Previously, Mueller (1986) reported that single-dose $\mathrm{Cd}$ administration increased lipid peroxidation and decreased GSH in the liver. Many investigators reported that the reduction of GSH levels leads to elevation of LPO (Baghi et al., 1996; El-Maraghy et al., 2001). The present study demonstrated that the levels of GSH in the tissues homogenates of testes were significantly declined in Cd-group comparing with controls. Various mechanisms were suggested to be responsible for the $\mathrm{Cd}$ toxicity. One of these mechanisms includes $\mathrm{Cd}$ binding to-SH groups from cell membrane proteins, cytoplasmic proteins, and enzymes. In addition, $\mathrm{Cd}$ can reduce activities of several enzymes including enzymes antioxidants (Xiao et al., 2002). In addition, the authors showed that in vitro and in vivo $\mathrm{Cd}$ administration in rats increased tissue lipid peroxidation. In agreement with the previous results, the current study revealed that the levels of LPO were significantly higher in Cdgroup than control group in the tissues 


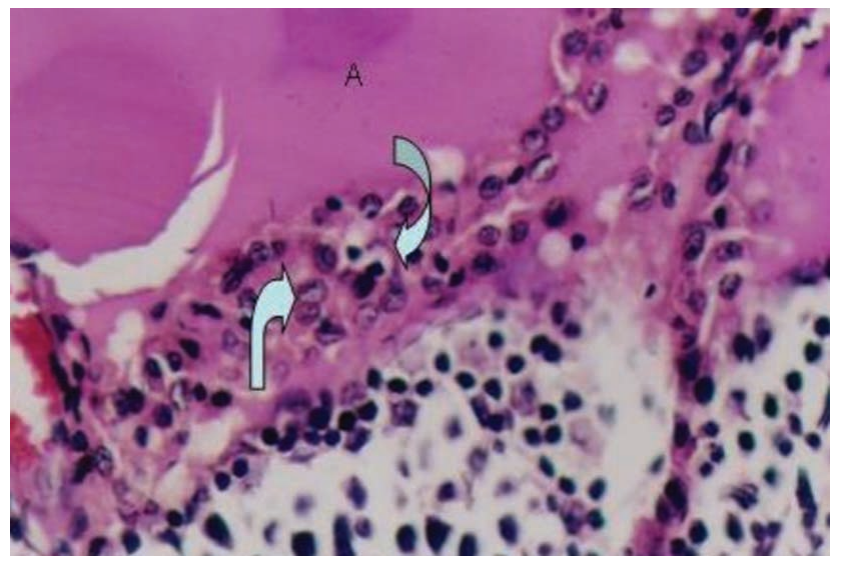

Fig. 5. Testes of male albino rats intoxicated with cadmium chloride alone showing Interstitial edema "eosinophilic structurless fluid "(A) and coagulative necrosis(Hollow curved arrows) (H\&E .X .400).

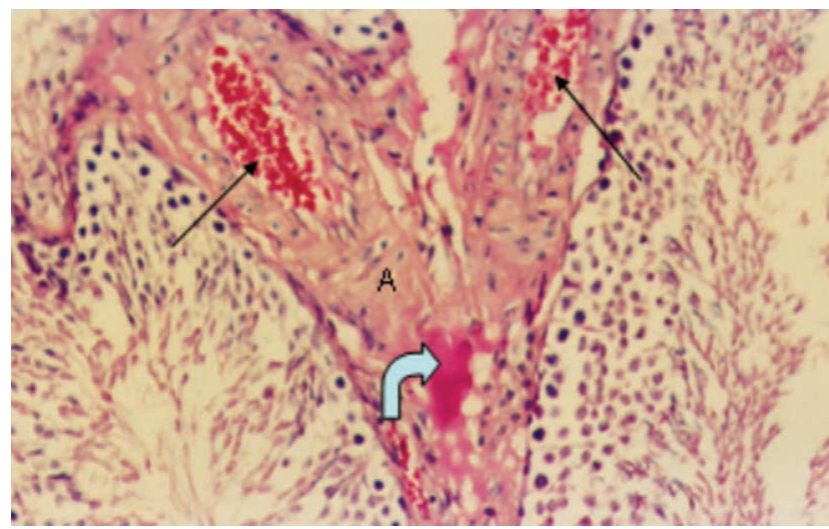

Fig. 6. Testes of male albino rats intoxicated with cadmium chloride alone showing: testicular edema (A), necrosis( curved hollow arrow) and severe congestion( thin arrows) (H\&E X . 200).

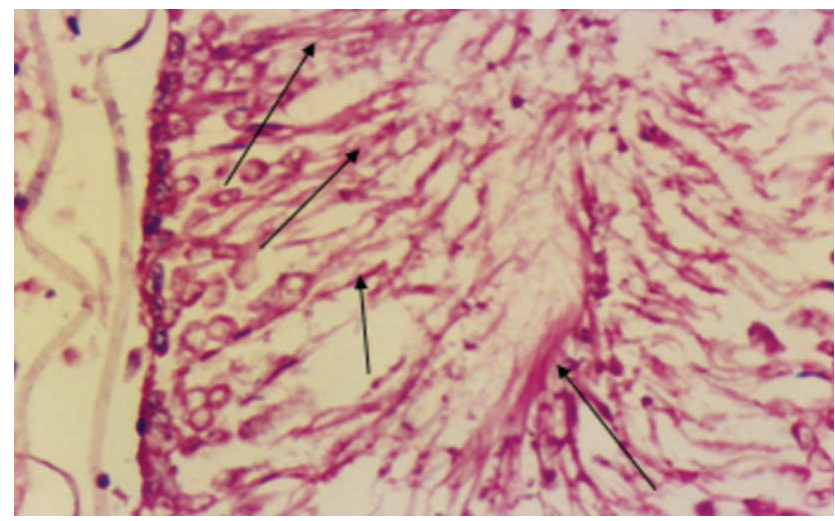

Fig. 7. Testes of male albino rats intoxicated with cadmium chloride alone showing complete testicular necrosis and sloughing of all layers ,Ischemic necrosis, (Arrows) (H\&E .X. 400).

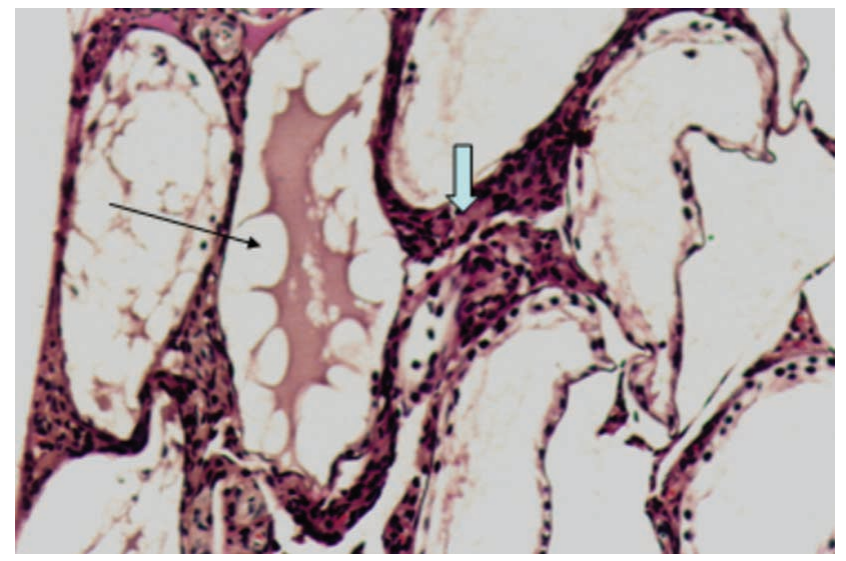

Fig. 8. Testes of male albino rats intoxicated with cadmium chloride alone showing cystic dilatation of seminiferous tubules (Thin arrow) and interstitial fibroplasia with mononuclear cells infiltrations( hollow arrow) (H\&E .X. 200)

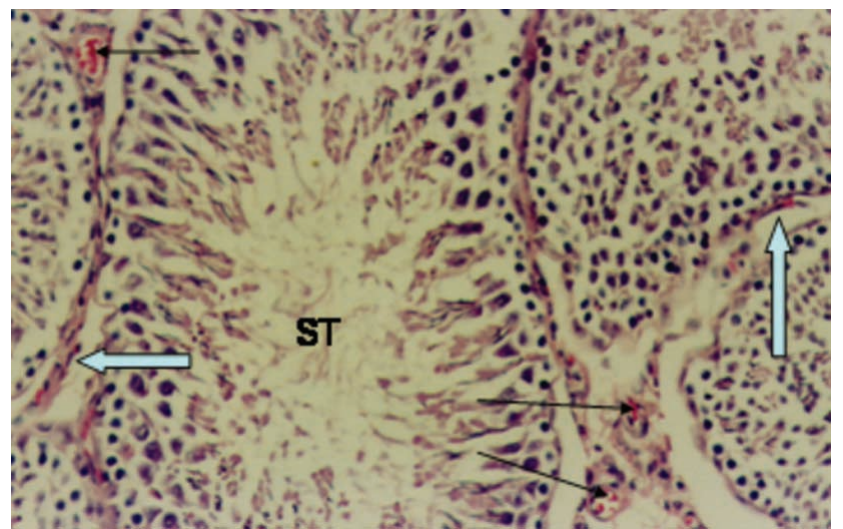

Fig. 9. Testes of male albino rats treated with chloride and green tea extract showing mild degenerative changes of seminiferous tubules (ST), mild congestion (thin arrows) and edema (hollow arrows) (H\&E .X. 200)

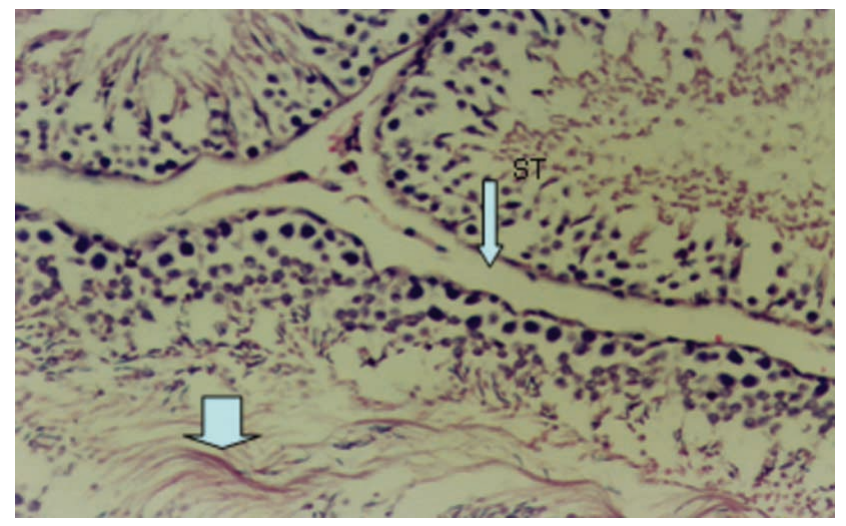

Fig. 10. Testes of male albino rats treated with cadmium chloride and green tea extract showing nearly normal seminiferous tubules with mild odema (Thin hollow arrow) and necrosis (Big hollow arrow) (H\&E.X. 200). 
homogenates of testes. Aruldhas reported that oxidative stress by free radical toxicity caused by Cd affected infertility. Moreover, Gupta and Kara found a significant elevation of LPO in testis tissue of rat treated with Cd. Stajn et al. (1997) and Patra et al. (1999) reported that different doses of Cd increase organ lipid peroxidation (LPO) in many organs including male sex organs and brought about changes in the antioxidant defence system.

In agreement with the results of Blanco et al. (2007), the current study showed marked morphological changes in the form of swelling, congestion, hemorrhage and multifocal areas of ischemic necrosis. However, Blanco et al. claimed that even with low doses of $\mathrm{Cd}$ chloride $(1 \mathrm{mg} / \mathrm{kg}$ for one month) induced lack of spermatogenesis and severe necrosis of the testes of rats. Moreover, Santos et al. reported that endothelial damage of the small blood vessels, edema and hemorrhage of the rate testes can be demonstrated by using just a single parenteral dose of Cd chloride at 2-4 mg/kg.

In consistent with previous reports Santos et al. and Blanco et al., the present study showed severe histological changes in $46.7 \%$ of the examined cases in the form of extensive widening of interstitial spaces due to diffuse oesinophilic, edematous vacuolated fluids infiltration, necrosis, congestion and hemorrhage. However, in $33.3 \%$ of the cases there were complete necrosis and sloughing of all layers of seminiferous tubules. Moreover, in $20 \%$ of the cases there were marked cystic dilatation, atrophy with fibrosis and complete absence of the sperms.

Reversal of the changes by green tea extract is consistent with the results of many investigators (Rana \& Verna, 1996; Shaikh \& Tang; Stohs et al.; Santos et al.) who recorded that the testes treated with $\mathrm{Cd}+\mathrm{GTE}$ showed mild edema and necrosis. However, the present study revealed that the reversal of morphological and histological changes by GTE varies from mild to moderate edema, congestion, necrosis and hemorrhage. These results are in agreement with the report of Paul who added that green tea acts as antioxidant and normalize testes metabolic disorders.

In the current study, the levels of LPO in GTE+ Cd group were significantly reduced comparing to $\mathrm{Cd}$-group. The levels of GSH in the GTE+Cd group were significantly elevated in comparison with Cd-treated group However, Ozdemir \& Dursun (2009) claimed that green tea constituents do not seem to be helpful against Cd toxicity. Contrarily, the results of the current study demonstrated that green tea by itself significantly improved damage from $\mathrm{Cd}$-induced oxidative stress. In addition, the testes of rats treated with Cd+GTE showed mild to moderate edema, congestion with minute foci of necrosis and hemorrhage.

\section{CONCLUSION}

The exposure to $\mathrm{Cd}$ induces histopathological and biochemical effects in rat testes. The increased oxidative stress resulted from $\mathrm{Cd}$ intoxication in testicular tissue might be responsible, at least in part, for histopathological changes. GTE had protective effect against Cd toxicity evidenced by reduction of LPO level, and minimal histological changes in the testes of rats treated with $\mathrm{Cd}+\mathrm{GTE}$.

EL-SHAHAT, A. E.; GABR, A.; MEKI, A. R. \& MEHANA, E. S. Morfología testicular alterada y stress oxidativo inducido por cadmio en ratas de experimentación y el efecto protector del extracto simultáneo del té verde. Int. J. Morphol., 27(3):757-764, 2009.

RESUMEN: El cadmio (Cd), es un contaminante del medio ambiente e industrial que afecta al sistema reproductivo masculino. Cd induce su efecto por afección de los sistemas enzimáticos antioxidantes de los tejidos. El extracto de té verde (ETV) es un antioxidante y buscador de radicales libres y tiene una propiedad quelante. El objetivo de este estudio fue investigar el efecto protector de ETV contra daños provocado por Cd a los testículos. Cuatro grupos de ratas macho, se utilizaron: Controles, tratados con ETV, tratados con $\mathrm{Cd}$ y tratados con $\mathrm{Cd}+\mathrm{ETV}$, todas las ratas tratadas con las mismas dosis. Las ratas recibieron ETV o Cd por vía oral en el agua potable. Después de 5 semanas, los animales fueron sacrificados y los testículos fueron retirados para la evaluación microscópica y bioquímica. Los niveles de peróxidos lípidos (LPO) y de glutation (GSH) fueron detectados en el tejido homogenizado de rata testículos. El estudio demostró marcados cambios morfológicos como inflamación, congestión, hemorragia y necrosis en los testículos de las ratas tratadas solamente con $\mathrm{Cd}$. Sin embargo, las ratas tratadas con Cd + ETV mostraron leves signos de edema, congestión y focos de necrosis en los testículos. Los niveles de LPO fueron significativamente mayores en comparación con el control y la de GSH fue significativamente menor en las ratas tratadas con Cd, pero cuando ETV fue co-administrado con $\mathrm{Cd}$, hubo una reducción efectiva en el estrés oxidativo, como lo demuestra el aumento significativo del nivel de GSH. En conclusión, las ratas recibieron GTE + Cd que podría aumentar el sistema antioxidante / desintoxicación, por tanto, reducir el estrés oxidativo en los testículos de ratas. El efecto beneficioso de GTE es reducir la toxicidad y el daño tisular causado Cd.

PALABRAS CLAVE: Testículos de rata; Toxicidad por cadmio; Extracto de té verde; Peróxidos lípidos; Glutatión.

\section{REFERENCES}

Alvarez, S. M.; Gómez, N. N.; Scardapane, L.; Zirulnik, F.; Martínez, D. \& Giménez, M. S. Morphological changes andoxidative stress in rat prostate exposed to a noncarcinogenic dose of cadmium. Toxicol. Lett., 153:36576, 2004. 
EL-SHAHAT, A. E.; GABR, A.; MEKI, A. R. \& MEHANA, E. S. Altered testicular morphology and oxidative stress induced by cadmium in experimental rats and protective effect of simultaneous green tea extract. Int. J. Morphol., 27(3):757-764, 2009.

Andersen, H. R. \& Andersen, O. Effect of cadmium chloride on hepatic lipid peroxidation in mice. Pharmacol. Toxicol., 63(3):173-7, 1988.

Aruldhas, M. M.; Subramanian, S.; Seker, P.; Vengatesh, G.; Chandrahasan, G.; Govindarajulu, P. \& Akbarasha M A. Chronic chromium exposure-induced changes in testicular histoarchitechitecture are associated with oxidative stress: study in a non-human primate (Macaca radiata Geoffroy). Hum. Reprod., 20:2801-13, 2005.

Bagchi, D.; Bagchi, M.; Hassoun, E. A.; \& Stohs, S. J. Cadmium-induced excretion of urinary lipid metabolites, DNA damage, glutathione depletion and hepatic lipid peroxidation in Sprague-Dawley rats. Biol. Trace Elem. Res., 52:143-54, 1996.

Bancroft, J. D. Histopathological stains and their diagnostic uses. Edinburgh, New York, Churchill Livingstone, 1975.

Blanco, A.; Moyano, R.; Vivo, J.; Flores-Acuña, R.; Molina, A.; Blanco, C.; Agüera, E. \& Monterde, J. G. Quantitative changes in the testicular structure in mice exposed to low doses of cadmium. Environ. Toxicol. Pharmacol. 23:96-101, 2007.

Challa, A.; Rao, D. R. \& Reddy, B. S. Interactive suppression of aberrant crypt foci induced by azoxymethane in rat colon by phytic acid and green tea. Carcinogenesis, 18:2023-6, 1997.

Diana, P. H. Effect of green tea polyphenols on cadmium toxicity in Coenorhabaditis elegons. NCDR, Poster session, No. 2, 2008.

Dutta, P.; Seirafi, J.; Halpin, D.; Pinto, J. \& Rivlin, R. Acute ethanol exposure alters hepatic glutathione metabolism in riboflavin deficiency. Alcohol, 12:43-7, 1995.

El-Maraghy, S. A.; Gad, M. Z.; Fahim, A. T. \& Hamdy, M. A. Effect of cadmium and aluminum intake on the antioxidant status and lipid peroxidation in rat tissues. J. Biochem. Mol. Toxicol., 15(4):207-14, 2001.

García-Fernández, A. J.; Bayoumi, A.E.; Pérez-Pertejo, Y.; Motas, M.; Reguera, R. M.; Ordóñez, C.; Balaña-Fouce, R. \& Ordóñez, D. Alterations of the glutathione-redox balance induced by metals in CHO-K1 cells. Comp. Biochem. Physiol. C. Toxicol. Pharmacol., 132:365-73, 2002.

Gupta, R. S.; Gupta, E. S.; Dhakal, B. K.; Thakur, A. R. \& Ahnn, J. Vitamin $\mathrm{C}$ and vitamin E protect the rat testes from cadmium - induced reactive oxygen species. Mol. Cells, 17(1):132-9, 2004.
Hertog, M. G. L.; Hollman, P. C. H. \& van de Putte, B. Content of potentially anticarcinogenic flavonoids of tea infusions, wines and fruit juices. J. Agric. Food Chem., 41:1242-6, 1993.

Kara, H.; Karatas, F.; Canatan, H. \& Servi, K. Effects of exogenous metallothionein on acute cadmium toxicity in rats. Bio. Trace. Elem. Res., 104(3):223$32,2005$.

Liu, J.; Liu, Y.; Michalska, A. E.; Andy Choo, K. H. \& Klaassen, C. D. Distribution and retention of cadmium in metallothionein I and II null mice. Toxicol. Appl. Pharmacol., 136:260-8, 1996.

Maity, S.; Vedasiromoni, J. R. \& Ganguly, D. K. Role of glutathione in the antiulcer effect of hot water extract of black tea (Camellia sinensis). Jpn. J. Pharmacol., 78:285-92, 1998.

Mueller, L. Consequences of cadmium toxicity in rat hepatocytes. Mitochondrial dysfunction and lipid peroxidation. Toxicology, 40:285-95, 1986.

Oteiza, P. I.; Adonaylo, V. N. \& Keen, C. L. Cadmiuminduced testes oxidative damage in rats can be influenced by dietary zinc intake. Toxicology, 137(1):13-22, 1999.

Ozdemir, S. \& Dursun, S. Role of $+(-)$ catechin against cadmium toxicity in the rat testes. Scand. J. Urol. Nephrol., 43(1):8-11, 2009.

Patra, R. C.; Swarup, D. \& Senapati. S. K. Effects of cadmium on lipid peroxides and superoxide dismutase in hepatic, renal and testicular tissue of rats. Vet. Hum. Toxicol., 41:65-7, 1999.

Paul, D. H. Effect of green tea polyphenols on cadmium toxicity in rats. Dominican. Edu. J., 6(2):1-10, 2008.

Rana, S. V. S. \& Verma, S. Protective effects of GSH, vitamin $\mathrm{E}$ and selenium on lipid peroxidation in cadmium-fed rats. Biol. Trace Elem. Res., 51:161-8, 1996.

Robards, K. \& Worsfold, P. Cadmium: toxicology and analysis. a review. Analyst 116:549-68, 1991.

Santos, F.W.; Oro, T.; Zeni, G..; Rocha, J. B. T.; do Nascimento, P. C. \& Nogueira, C. W. Cadmium induced testicular damage and its response to administration of succimer and diphenyl diselenide in mice. Toxicol. Lett., 152:255-63, 2004.

Sato, M. \& Takizawa, Y. Cadmium-binding proteins in 
human organs. Toxicol. Lett., 11(3-4): 269-73, 1982.

Shaikh, Z. A. \& Tang, W. Protection against chronic cadmium toxicity by glycine. Toxicology, 132(2):139-46, 1999.

Stajn, A.; Zikic, R.; Ognjanovic, V. B.; Saicic, Z. S.; Pavlovic, S. Z.; Kostic, M. M. \& Petrovic, V. M. Effect of cadmium and selenium on the antioxidant defense system in rat kidneys. Comp. Biochem. Physiol. C. Pharmacol. Toxicol. Endocrinol., 117C:167-72, 1997.

Stohs, S. J.; Bagchi, D.; Hassoun, E. \& Bagchi, M. Oxidative mechanisms in the toxicity of chromium and cadmium ions. J. Environ. Pathol. Toxicol. Oncol., 20:77-88, 2001.

Tandon, S. K.; Singh, S.; Prasad, S.; Khandekar, K.; Dwivedi, V. K.; Chatterjee, M. \& Mathur, N. Reversal of cadmium induced oxidative stress by chelating agent, antioxidant or their combination in rat. Toxicol. Lett., 145:211-7, 2003.

Thayer, W. S. Serum lipid peroxides in rats treated chronically with adriamycin. Biochem. Pharmacol., 33(14):2259-63, 1984.

Xiao, P.; Jia, X. D.; Zhong, W. J.; Jin, X. P. \& Nordberg, G. Restorative effects of zinc and selenium on cadmiuminduced kidney oxidative damage in rats. Biomed. Environ. Sci., 15:67-74, 2002.

Yu, H. N.; Shen, S. R. \& Yin, J. J. Effects of metal ions, catechins, and their interactions on prostate cancer . Crit. Rev. Food Sci. Nutr., 47(8):711-9, 2007.

Correspondence to:

Dr. Abd El-Rahman El-Shahat

Department of Anatomy

Faculty of Medicine,

Cairo University

EGYPT

Email: khalilabdulrahman@yahoo.com

Received: 18-06-2009

Accepted: 22-07-2009 